\title{
KAJIAN NILAI PENDIDIKAN AGAMA HINDU DALAM KONSEP MANYAMA BRAYA
}

\author{
Oleh \\ Ida Bagus Putu Eka Suadnyana
}

\begin{abstract}
The concept of Manyama Braya (Hindu Social Mutual Assistance) was used as a guideline by the people in the custom village of Sukawati because it is one of the existing local wisdom and even developed. The value of local wisdom, Manyama Braya implies an equality and fraternity or social recognition that we are brothers as a social fraternity; therefore the attitude and behavior of ours have to look at others as brothers who should be invited together in joy and sorrow. The concept of Manyama Braya was emphasized in daily life by the people in the custom village of Sukawati. This study was as a background of research of value Religious Hindu Education in the concept of Manyama Braya. The concept of Manyama Braya was important to be applied because the society in the village wanted to get prosperity and harmony in the society life. (2) The concept of Manyama Braya were implemented in a custom activity which were included Dewa Yadnya (Offering to Gods), Manusa Yadnya (Offering to people), Pitra Yadnya (Offering to ancestors) and Bhuta Yadnya (Offering to supernatural) and the concept of Manyama Braya was also implemented in everyday life. (3) The education values contained in the application of the concept of Manyama Braya namely: the value of ethics education was shown when the people always kept ethics in conducting customs activities. The value of harmony education was shown when the people always together kept maintaining harmonious indigenous activities and daily life. And the value of social education, was shown when the people work together in performing traditional custom activities and mutual assistance in everyday life.
\end{abstract}

Keywords : Manyama Braya, The education values, Hindu Social Mutual Assistance

\section{PENDAHULUAN}

Desa Pakraman merupakan sebuah kumpulan atau organisasi atau lembaga yang berada di atas beberapa dusun atau Banjar. Susunan dari beberapa dusun atau Banjar dalam adat masyarakat Bali disebut dusun adat atau Banjar adat. Sementara Banjar adat merupakan kumpulan individu-individu dari anggota keluarga. Pelembagaan ajaran agama Hindu di Bali tidak bisa lepas dari lembaga desa Pakraman yang mewadahi tradisi adat istiadat. Desa Pakraman di Bali ada dua macam yaitu, desa adat dan desa dinas (Sirtha, 2008: 20). 
Desa Pakraman dimaknai sebagai desa yang memiliki aturan adat sendiri dan terbentuk berdasarkan konsep Tri Hita Karana. Tri Hita Karana dalam konsep umat Hindu merupakan bentuk ikatan yang terjalin erat didalam kehidupan antar berbagai golongan. Ikatan berbagai golongan tersebut yaitu: (1). Parahyangan yaitu hubungan baik manusia dengan tuhan, dapat diwujudkan dalam upacara Dewa yadnya, (2). Pawongan yaitu hubungan manusia dengan sesama manusia, di wujudkan dengan upacara Rsi yadnya, Manusa yadnya dan Pitra yadnya. (3). Palemahan yaitu hubungan manusia dengan alam lingkungan, diwujudkan dengan upacara Bhuta yadnya.

Tata cara di lingkungan masyarakat Bali yang mengacu pada konsep Tri Hita Karana, khususnya dalam desa Pakraman terdapat tiga bentuk pembagian tata cara dalam melakukan aktivitas di lingkungan masyarakat Bali yaitu: (1). Parahyangan, merupakan kahyangan tiga (tiga tempat suci yang harus dimiliki desa adat) (2). Palemahan merupakan masyarakat desa Pakraman (krama desa adat), dan (3). Pawongan, merupakan "asengka” balai agung (Sudira, 2008: 10).

Manusia sebagai makhluk sosial perlu dan selalu berinteraksi atau berkomunikasi dengan manusia lain. Komunikasi dapat terjadi dimana saja dan kapanpun saja, dengan demikian interaksi atau komunikasi merupakan bagian yang integral dari kehidupan sehari-hari bahkan dapat dikatakan sebagai manifestasi kehidupan sehari-hari (Tim penyusun, 2007: 3). Keberadaan Desa Pakraman di Bali tidak bisa lepas dari konsep Manyama Braya, Manyama Braya adalah salah satu kearifan lokal yang patut dilestarikan dan bahkan ditumbuh kembangkan. Nilai kearifan lokal Manyama Braya, mengandung makna persamaan persaudaraan dan pengakuan sosial bahwa kita adalah bersaudara, sebagai satu kesatuan sosial persaudaraan maka sikap dan perilaku dalam memandang orang lain sebagai saudara yang patut diajak bersama dalam suka maupun duka. Kata Manyama Braya sering terdengar berkaitan dengan Yadnya di Bali, ada juga yang mengungkapkan bahwa Manyama Braya sama dengan gotong-royong demi berbagi kebahagiaan dan kasih. Melakukan kegiatan secara bersama-sama sehingga berat sama dipikul, ringan sama dijinjing. Sistem kemasyarakatan di Bali menyarankan kita untuk menerapkan konsep Manyama Braya agar tercipta kesejahteraan dan kerukunan antar umat beragama. Itulah yang diwujudkan di Desa Pakraman di Bali. 
Desa Pakraman di Bali bukan hanya desa-desa yang ada di wilayah Bali pedalaman. Banyak juga terdapat Desa Pakraman yang terletak pada daerah padat penduduk dan merupakan daerah tujuan wisata. Berdasarkan realita ini, sangat menarik untuk melakukan penelitian tentang kajian nilai pendidikan Agama Hindu dalam konsep Manyama Braya di Desa Pakraman yang ada di Bali.

\section{PEMBAHASAN}

\section{A. Pentingnya Penerapan Konsep Manyama Braya pada Desa Pakraman di Bali}

Manyama Braya adalah suatu kearifan lokal yang patut dilestarikan bahkan ditumbuh kembangan. Nilai kearifan lokal Manyama Braya mengandung makna persamaan dan persaudaraan dan pengakuan sosial bahwa kita adalah bersaudara sebagai satu kesatuan sosial persaudaraan maka sikap dan perilaku dalam memandang orang lain sebagai saudara yang patut diajak bersama-sama dalam suka dan duka. Dalam bahasa Indonesia "Manyama" berarti bersaudara, sedangkan "Braya" berarti kerabat, yaitu persaudaraan yang erat dalam berpartisipasi dalam kegiatan Masuka-duka (Utami, $2010: 2$ ).

Konsep Manyama Braya sangat penting diterapkan di Desa Pakraman yang ada di Bali, Karena di dalam Awig-awig sudah dimuat, paguyuban di Desa Pakraman yaitu, segilik, seguluk, selunglung, sebayantaka, paras-paros, sarpanaya. Nilai-nilai luhur itu diharapkan berfungsi sebagai suatu pedoman yang memberi arah dan orientasi kepada kehidupan warga masyarakat. Dalam kehidupan bermasyarakat, konsep Manyama braya berperan sangat penting dan sangat berpengaruh dalam kehidupan bermasyarakat, karena masyarakat Desa Pakraman di Bali sangat menginginkan keharmonisan dan kesejahteraan dalam kehidupan bermasyarakat, karena pada hakikatnya sebagai anggota masyarakat kita patut saling membantu dalam kehidupan sehari-hari, karena manusia sebagai makhluk sosial akan saling membutuhkan.

Pada dasarnya konsep Manyama Braya sangat penting diterapkan pada Desa Pakraman di Bali. Karena tanpa menerapkan konsep Manyama Braya, tidak akan tercipta suasana yang rukun dan harmonis sehingga pelaksanaan kewajiban Dharma Agama dan Dharma Negara tidak akan bisa berjalan dengan baik. Semua pekerjaan jika dikerjakan bersama-sama dengan semangat gotong-royong, maka 
akan terasa lebih ringan dan mudah, disertai dengan pengamalan ajaran-ajaran Agama Hindu yang inklusif, humanis, fluralis dan dialogis serta menjunjung tinggi prinsip Shanti. Semoga Panyama Brayan pada Desa Pakraman di Bali selalu dipelihara dan diwarisi ke generasi berikutnya.

Konsep Manyama Braya sangat penting diterapkan pada Desa Pakraman di Bali, karena dengan menerapkan konsep Manyama Braya, akan tercipta keharmonisan dan kesejahteraan dalam kehidupan bermasyarakat. seperti yang dilakukan masyarakat Desa Pakraman dalam melakukan kegiatan adat maupun kehidupan sehari-hari, selalu berpedoman pada konsep Manyama Braya, yang biasanya dilakukan dalam kegiatan Ngayah atau nguopin. Oleh karena itu konsep Manyama Braya sangat berperan penting dalam kelangsungan hidup bermasyarakat pada Desa Pakraman di Bali, dan hendaknya selalu diterapkan dan diwariskan secara turun temurun.

Dari beberapa uraian di atas, dapat disimpulkan bahwa konsep Manyama Braya yang dijadikan pedoman oleh masyarakat pada Desa Pakraman di Bali, berperan sangat penting dalam menuntun kehidupan bermasyarakat khususnya pada Desa Pakraman di Bali dan diharapkan bisa dilestarikan dan dibina, sejalan dengan bergulirnya waktu serta perubahan-prubahan yang terjadi dalam kehidupan masyarakat perlu terus disesuaikan dan dikembangkan sejalan dengan tuntutan jaman dan perkembangan masyarakatnya.

Berpegangan pada konsep Manyama braya yang dijadikan pedoman pada Desa Pakraman di Bali dalam pelaksanaan Dharma Agama dan Dharma Negara. Disertai dengan pengamalan ajaran Tri Hita Karana, dalam hal ini peranan konsep Manyama Braya diharapkan dapat menyelaraskan hubungan manusia dengan Tuhan (Prahyangan), hubungan manusia dengan manusia (Pawongan), dan hubungan manusia dengan alam (Palemahan). Konsep Manyama Braya juga mengajarkan untuk mengamalkan ajaran Tat Twam Asi yaitu, aku adalah engkau dan engkau adalah aku, apabila prinsip ini dijalankan maka akan tercipta keselarasan dan keharonisan dalam kehidupan bermasyarakat.

Dalam hal ini sudah sangat jelas, bahwa konsep Manyama Braya sangat penting sekali diterapkan pada Desa Pakraman di Bali, guna mewujudkan 
keselarasan dan kesejahteraan atas dasar Masuka-duka sebagai warga masyarakat yang merupakan suatu kesatuan sosial.

\section{B. Kegiatan yang menerapkan konsep Manyama Braya pada Desa Pakraman di Bali}

Kehidupan sosial gotong royong dalam masyarakat Bali sering disebut dengan istilah Manyama Braya. Konsep Manyama Braya merupakan kearifan lokal yang sangat diperlukan dalam kehidupan umat beragama. Semua akan bisa terlaksana dengan baik dengan adanya kerjasama antar individu maupun kelompok masyarakat. Berikut adalah kegiatan-kegiatan yang menerapkan konsep Manyama Braya pada Desa Pakraman di Bali.

\section{B.1 Dalam Kegiatan Adat}

Umat Hindu memiliki berbagai macam kegiatan yang merupakan wujud bhakti kehadapan Ida Sang Hyang Widhi Wasa. begitu juga pada Desa Pakraman di Bali, salah satunya adalah upacara Yadnya. Yadnya adalah korban suci tulus ikhlas, Yadnya dibagi menjadi dua kelompok yaitu: Yadnya yang berkaitan dengan upacara dan Yadnya yang tidak berkaitan dengan upacara. Yadnya yang berkaitan dengan upacara dalam ajaran Agama Hindu disebut Panca Yadnya. Pelaksanaan Panca Yadnya dibagi menjadi lima bagian yaitu, Dewa Yadnya, Pitra Yadnya, Rsi Yadnya, Manusia Yadnya dan Bhuta Yadnya.

Masyarakat merupakan kesatuan hidup manusia yang berinteraksi menurut suatu sistem adat istiadat tertentu, yakni bersifat Continue dan terikat oleh suatu rasa identitas bersama melakukan berbagai aktivitas. Aktivitas itu dilakukan bersama-sama dengan manusia lainnya untuk mencapai cita-cita individual dan sosial (Koentjaraningrat, 1990: 146). Begitu juga yang dilakukan masyarakat pada Desa Pakraman di Bali.

Konsep Manyama Braya pada Desa Pakraman di Bali dilaksanakan di segala kegiatan Adat, karena kehidupan sosial dan gotong royong sangat diperlukan dalam kehidupan umat beragama khususnya Agama Hindu Bali, dalam melakukan kegiatan Adat. Semua bisa terlaksana dengan baik dengan adanya kerja sama antar individu maupun kelompok masyarakat. Konsep Manyama Braya selalu diterapkan dalam kegiatan Adat pada Desa Pakraman di Bali. Kegiatan-kegiatan Adat tersebut yang merupakan bagian dari Panca Yadnya yaitu, Dewa Yadnya, Manusa Yadnya, 
Pitra Yadnya dan Bhuta Yadnya dilakukan bersama-sama atas dasar rasa persaudaraan dan Panyama Brayan yang erat. Masyarakat Desa Pakraman Sukawati selalu bergotong-royong dalam pelaksanaan kegiatan Adat tersebut dalam bentuk Ngayah atau Nguopin, karena jika tidak dilaksanakan secara bersama-sama atau bergotong-royong sudah barang tentu akan menghambat proses pelaksanaan kegiatan-kegiatan Adat tersebut.

Masyarakat Bali yang dikenal dengan budaya keagamaannya yaitu suatu upacara keagamaan atau upacara Yadnya dengan konsep Ngayah dalam suatu upacara Yadya yang diadakan di Pura dan konsep Nguopin dalam ruang lingkup upacara Yadnya dalam konteks pribadi. Semua kegiatan-kegiatan adat tersebut akan lebih lancar jika dikerjakan secara bergotong royong, atas dasar Manyama Braya, Segilik Seguluk, Selunglung, Sebayantaka, Pekedek-Pekenyum, secara bersamasama mengerjakan semua proses kegiatan-kegiatan Adat tersebut.

Kegiatan-kegiatan Adat dalam bentuk Yadnya sangat membutuhkan kekompakan dalam bergotong-royong. Tanpa adanya sikap gotong royong proses maupun pelaksanaan Yadnya tersebut tidak akan berjalan dengan baik. Dengan berpedoman kepada konsep Manyama Braya masyarakat desa Pakraman di Bali bersama-sama baik dalam suka maupun duka melaksanakan proses dan pelaksanaan Yadnya sampai dengan selesai.

\section{B.2 Dalam Kehidupan Sehari-hari}

Kehidupan sosial dan gotong-royong sangat diperlukan dalam kehidupan sehari-hari. Manusia sebagai makhluk sosial, pada kenyataannya selalu mengadakan hubungan atau berinteraksi dengan orang lain, baik secara langsung maupun secara tidak langsung (Bhaskara, 2012: 2). Kehidupan sosial dan gotongroyong dalam masyarakat Bali disebut Manyama Braya. Konsep Manyama Braya dilaksanakan di segala lini kegiatan dan kehidupan sehari-hari. Banyak bentuk penerapan konsep Manyama Braya dalam kehidupan sehari-hari pada Desa Pakraman di Bali misalnya, nulungin (membantu) dalam kegiatan pembangunan rumah, membersihkan gang, Ngejot ke tetangga atau saudara dan kegiatan-kegiatan lain yang mungkin tidak bisa disebutkan satu-persatu. Konsep Manyama Braya 
memang diterapkan dalam kehidupan sehari-hari oleh masyarakat pada Desa Pakraman di Bali dengan berbagai bentuk penerapannya.

Konsep Manyama Braya sangat ditekankan dalam kehidupan sehari-hari oleh masyarakat pada Desa Pakraman di Bali, karena masyarakat Desa Pakraman menginginkan terwujudnya kerukunan dan keharmonisan antar masyarakat. Ada banyak macam bentuk penerapan konsep Manyama Braya dalam kehidupan sehari pada Desa Pakraman di Bali misalnya, metulung atau nguopin saat tetangga sedang membangun rumah, meminjamkan sepeda motor atau mobil, meminjamkan prabotan dapur atau prabotan yang lain kepada tetangga saat tetangga melakukan kegiatan Yadnya, dan masih banyak lagi penerapan konsep Manyama Braya dalam kehidupan sehari-hari yang tidak mungkin disampaikan satu-persatu.

\section{Nilai-Nilai Pendidikan yang terdapat dalam konsep Manyama Braya pada Desa Pakraman di Bali}

Manyama Braya dikatakan sebagai tali persaudaraan atau hubungan sosial atas dasar kekeluargaan, dengan kata lain Manyama Braya merupakan tali kasih persaudaraan di dalam bermasyarakat. Jika kita menyimak tata laksana konsep Manyama Braya akan tampak adanya nilai-nilai Pendidikan yang perlu dilestarikan sebagai perwujudan jati diri moral budaya bangsa kita pada umumnya. Beberapa nilai yang perlu kita ungkap disini adalah sebagai berikut:

\section{C.1 Nilai Pendidikan Etika}

Etika adalah bentuk pengendalian diri dalam hidup bersama (tim penyusun, 1994 : 89). Dalam etika seseorang dinilai tingkah lakunya, baik atau buruknya perbuatan seseorang itu. Etika sangat lumrah dengan istilah tata susila, yaitu merupakan pedoman bertingkah laku masyarakat dalam menjalani hidupnya. Landasan pemahaman etika ini dapat dilihat dari ajaran Tri Kaya Parisudha. Yang dimaksudkan yaitu kesucian atas lahir dan batin dari pikiran, perkataan, dan perbuatan yang senantiasa tercermin dalam kehidupan sehari-hari. Dengan demikian landasan etika yang dimaksud dalam hal ini adalah adanya keselarasan antara perkataan, perbuatan yang digerakan oleh jalannya pikiran menuju keharmonisan.

Hal ini dapat dilihat dalam kitab Sarasamuscaya 5.77 yang berbunyi : 


\section{Tadevapaharayenam tasmat}

\section{Kalvanama acaret}

\section{Yang artinya:}

Sebab yang membuat orang dikenal adalah perbuatannya, pikirannya, ucapan-ucapannya, hal inilah yang sangat menarik perhatian orang untuk mengetahui kepribadian seseorang, oleh karena itu hendaklah yang baik itu selalu di biasakan dalam laksana, perbuatan dan pikiran.

Laksana (perbuatan), perkataan dan pikiran itu disebut dengan Tri Kaya Parisudha adalah tiga yang harus disucikan. Maksudnya ketiga itu dilaksanakan dengan baik, karena pada dasarnya ketiga hal tersebut akan dapat kita jumpai apabila kita melakukan interaksi dan komunikasi baik dalam lingkungan keluarga, maupun dalam lingkungan keluarga.

Sama seperti yang dilakukan oleh masyarakat Desa Pakraman di Bali, selalu menjaga etika dan disiplin atas dasar konsep Manyama Braya dalam suatu rangkaian upacara Yadnya. Semua masyarakat atau Krama hendaknya menjaga kelancaran suatu kegiatan Yadnya dengan tidak berkata-kata kasar, tidak melakukan perbuatan yang tidak sopan, serta tidak mempunyai pikiran jahat yang nantinya dapat membahayakan orang lain atau diri sendiri. Konsep Manyama Braya pada Desa Pakraman di Bali yang diwarisi hingga sekarang, diharapkan tetap menjadi pedoman dalam semua kegiatan-kegiatan Yadnya yang dilakukan pada Desa Pakraman di Bali agar individu-individu yang terlibat dalam suatu kegiatan Yadnya tersebut mampu berinteraksi dengan baik, membina solidaritas guna tercapainya tujuan Yadnya yang baik serta memupuk dan mempererat tali persaudaraan antar warga Desa Pakraman Sukawati.

Manusia sebagai makhluk sosial di dalam menjalankan kehidupannya sangat bergantung pada masyarakat dimana mereka berada. Kekompakan masyarakat adalah kekompakan yang lahiriah dan dan rohaniah karena segala sesuatunya dipertimbangkan dan dikerjakan bersama dengan kesadaran. Manusia di dalam hidupnya selaku makhluk ciptaan Tuhan selain dibebani tanggung jawab, mendapatkan hak juga mempunyai kewajiban untuk melaksanakan Yadnya dan pengorbanan. Dalam penerapan konsep Manyama Braya pada Desa Pakraman di Bali dapat memberikan pencerahan etika dan moralitas, karena dalam konsep Manyama Braya mencerminkan perilaku kehidupan manusia yang harmonis sehingga dapat mengarahkan setiap orang untuk selalu saling menghargai 
menghormati satu sama lain. Karena Manyama Braya dapat diartikan bahwa kita bersaudara dalam satu ikatan yang erat.

\section{C.2 Nilai Pendidikan Kerukunan}

Kerukunan merupakan kebutuhan bersama yang tidak dapat dihindarkan ditengah perbedaan. Perbedaan yang ada merupakan penghalang untuk hidup rukun dan berdampingan (Bhaskara 2012: 3). Dalam ajaran Agama Hindu menterjemahkan sebagai "tiga penyebab kebahagiaan" yakni hubungan yang harmonis antara manusia dengan Tuhan, antara manusia dengan sesama manusia, dan antara manusia dengan alam atau lingkungannya yang disebut Tri Hita Karana. Tri Hita Karana berada dalam bhuana alit dan bhuana agung, pada bhuana alit terdiri atas atma, prana, (sabda, bayu, idep), dan sarira sebagai wadahnya. Dalam bhuana agung terdiri dari Pramatma (Ida Sang Hyang Widhi Wasa), prana-nya terdiri dari kekuatan memutar planet, tenaga laut, angin, listrik, dan arus Panca Maha Butha selalu totalitas sarira-nya bhuana agung. Terkait dengan konsep Tri Hita Karana, maka dalam masyarakat Desa Pakraman di Bali memang benar-benar mengimplementasikan ajaran kerukunan dalam konsep Manyama Braya secara langsung dapat menjaga keharmonisan atau kerukunan antar masyarakat.

Manusia pada hakekatnya manusia terlahir dilengkapi unsur cipta, rasa dan karsa. Dalam ajaran Agama Hindu disebut dengan istilah Tri Premana yakni, bayu, sabda dan idep. Terlahir menjadi manusia merupakan suatu keberuntungan, dapat menolong dirinya dari samsara dengan cara berbuat baik, patut berguru atau memohon tuntunan melalui sabda-nya yang tertuang dalam kitab suci veda. Dengan demikian sesuai dengan apa yang tertuang dalam kitab Sarasamuscaya 6, yang menggariskan keutamaan menjadi manusia sebagai berikut:

Pharamarthanya pengpengen ta pwa katemwaniking si dadi wwang, Durlabha vi vat ta. Saksat handaning mara ring swarga ika, sanimittaning tan tiba muwah ta pwa damelakena.

Terjemahannya:

Pergunakanlah dengan sebaik-baiknya kesempatan menjelma sebagai manusia ini, kesempatan yang sungguh sulit diperoleh, yang merupakan tenaga untuk pergi ke surga, segala sesuatu yang menyebabkan agar tidak jatuh lagi, itulah hendaknya dilakukan.

Manyama Braya mewujudkan kerukunan antara hubungan manusia dengan manusia dimana masyarakat selalu saling menghormati dan saling menghargai, 
selalu bersama-sama Masuka duka dalam semua kegiatan Ngayah atau Nguopin yang dilaksanakan pada Desa Pakraman di Bali. Dalam konsep Manyama Braya terdapat nilai kerukunan yaitu antara hubungan manusia dengan manusia, itu terlihat saat semua Krama atau masyarakat Desa Pakraman di Bali melakukan kegiatan Ngayah atau nguopin dengan bergotong royong dan saling menghormati dan menghargai, dan semua itu tercantum dalam konsep Tri Hita Karana.

\section{C.3 Nilai Pendidikan Sosial}

Manusia sebagai makhluk sosial perlu dan selalu berkomunikasi dengan manusia lain. Komunikasi dapat terjadi dimana saja dan kapan saja, dan semua itu juga terjadi dalam kebersamaan seluruh warga atau Krama di dalam upacara keagamaan atau upacara Yadnya yang mempunyai nilai yang sangat penting.

Upacara keagamaan pada dasarnya merupakan salah satu cabang dari kerangka dasar Agama Hindu yang memiliki nilai penting dalam berbagai aspek kehidupan manusia baik sosial maupun spiritual. Berpedoman dengan konsep Manyama Braya akan memberikan dorongan solidaritas pada masyarakat dalam rangka mempersatukan, kemauan niat dan perasaan mereka dalam melakukan kegiatan-kegiatan keagamaan atau Yadnya secara bergotong-royong pada Desa Pakraman di Bali. Terdapat nilai Pendidikan sosial dalam penerapan konsep Manyama Braya pada Desa Pakraman di Bali saat masyarakat melakukan kegiatankegiatan secara bergotong-royong. Kehidupan sosial dan gotong royong sangat diperlukan sangat diperlukan dalam kehidupan umat beragama. Semua akan bisa berjalan dengan lancar atau terlaksana dengan baik dengan adanya kerjasama antar individu maupun kelompok masyarakat. Begitu juga dalam kegiatan-kegiatan Panca Yadnya dengan menerapkan konsep Manyama Braya yaitu bergotong royong, semua akan terasa menjadi lebih mudah karena dikerjakan secara bersamasama atas dasar rasa persaudaraan atau Panyama Brayan yang kuat.

Adanya suatu kebersamaan dalam setiap masyarakat selalu dibutuhkan suatu komunikasi yang efektif, dimana semua hal itu akan dapat terwujud dengan selalu mengimplementasikan konsep Manyama Braya. Tanpa adanya komunikasi yang baik dan rasa Panyama Brayan yang erat sudah barang tentu kegiatankegiatan Panca yadnya tidak akan bisa berjalan dengan baik pada Desa Pakraman di Bali.Masyarakat merupakan kesatuan hidup manusia yang berinteraksi menurut 
suatau sistem adat istiadat tertentu, yakni bersifat continue dan terkait oleh suatu ras dan identitas bersama melakukan aktivitas. Aktivitas itu dilakukan bersamasama dengan manusia lainnya untuk mencapai cita-cita individual dan sosial (Koentjaraningrat, 1990: 146). Begitu pula dengan masyarakat pada Desa Pakraman di Bali, berpedoman dengan konsep Manyama Braya, selalu bersamasama saling membantu dalam suka maupun duka melakukan semua kegiatankegiatan dengan menjunjung tinggi nilai Agama guna terciptanya keselarasan dan keharmonisan antar masyarakat.

\section{SIMPULAN}

Dari uraian diatas dapat disimpulkan mengenai Konsep Manyama Braya penting diterapkan pada Desa Pakraman di Bali karena, masyarakat pada Desa Pakraman di Bali menginginkan adanya keharmonisan dan kerukunan antar masyarakat khususnya pada Desa Pakraman di Bali. Konsep Manyama Braya ini diterapkan dalam kehidupan sehari-hari maupun dalam kegiatan adat oleh masyarakat Desa Pakraman di Bali. Konsep Manyama Braya dilaksanakan dalam kegiatan adat yang meliputi, Dewa Yadnya, Manusa Yadnya, Pitra Yadnya dan Bhuta Yadnya. Kegiatan-kegiatan adat tersebut diwujudkan dalam bentuk Ngayah saat kegiatan Dewa Yadnya atau Nguopin saat kegiatan Manusa Yadnya, Pitra Yadnya maupun Bhuta Yadnya. Konsep Manyama Braya juga diterapkan dalam kehidupan sehari-hari, diwujudkan dalam bentuk membantu tetangga dalam kegiatan pembangunan rumah, meminjamkan sepeda motor, meminjamkan mobil, dan meminjamkan tetangga prabotan-prabotan dapur saat tetangga melakukan kegiatan yadnya di rumahnya. Nilai-Nilai Pendidikan yang terdapat dalam konsep Manyama Braya yaitu: (1) Nilai Pendidikan etika : Pendidikan etika dalam konsep Manyama Braya pada Desa Pakraman di Bali, ditunjukkan saat semua masyarakat atau Krama pada Desa Pakraman di Bali brsama-sama, atas rasa Manyama Braya yang erat selalu menjaga kelancaran suatu kegiatan Yadnya dengan tidak berkatakata kasar, tidak melakukan perbuatan yang tidak sopan, serta tidak mempunyai pikiran jahat yang nantinya dapat membahayakan orang lain atau diri sendiri. (2) Nilai Pendidikan kerukunan, Pendidikan kerukunan Dalam konsep Manyama Braya pada Desa Pakraman di Bali ditunjukkan saat masyarakat menjaga kerukunan antar masyarakat dimana masyarakat selalu saling menghormati dan 
saling menghargai, selalu bersama-sama Masuka duka dalam semua kegiatan yang dilaksanakan pada Desa Pakraman di Bali atas dasar rasa Manyama Braya. Terkait dengan konsep Tri Hita Karana, maka dalam masyarakat Desa Pakraman di Bali memang mengimplementasikan ajaran kerukunan dalam konsep Manyama Braya secara langsung dapat menjaga keharmonisan atau keseimbangan antara manusia dengan Tuhan, antara manusia dengan manusia, dan antara manusia dengan lingkungannya. (3) nilai pendidikan sosial, nilai Pendidikan sosial dalam konsep Manyama Braya pada Desa Pakraman di Bali ditunjukkan dalam kehidupan seharihari yaitu saling bantu-membantu saat tetangga atau masyarakat lain membutuhkan bantuan, dan dalam kegiatan Yadnya yaitu saat masyarakat bersama-sama secara bergotong-royong melakukan tradisi Ngayah atau Nguopin.

\section{DAFTAR PUSTAKA}

Bhaskara, I Wayan Open Jana. 2012. Implementasi Awig-awig Pada Masyarakat pada Desa Pakraman di Bali, Kecamatan Sukawati, Kabupaten Gianyar. (Skripsi). Denpasar: IHDN Denpasar.

Bungin, Barhan. 2003. Analisis Data Penelitian Kualitatif Pemahaman Filosofi dan Metodologis Kearah Penguasaan, Model Aplikasi. Jakarta: PT. Raja Grafindo Persada.

Kaelan, H. 2002. Metode Penelitian Agama Kualitatif Interdisipliner. Yogyakarta: Paradigma.

Koentjaraningrat, Prof. Dr. 1982. Metode-metode Penelitian Masyarakat. Jakarta: Gramedia.

Pacanowsky, M.E., \& O’Donell-Trujillo, M. 1982. Comunication and Organizational Cultures. Western Journal of Speech Comunication. 46, 115 130.

Poerwadarminta, W.J.S. 1984 1995. Kamus Umum Bahasa Indonesia. Edisi Revisi. Jakarta: PN. Balai Pustaka.

Sudira, Bambang Oka. 2008. Konsep Filosofi Hindu Dalam Desa Adat Kebudayaan Bali. Surabaya: Paramita.

Surpha, I Wayan. 1991. Eksistensi Desa Adat di Bali. Denpasar: Upasada Sastra. 
Tim Penyusun Pemda Tk.I Bali. 1990. Agama Hindu untuk Perguruan Tinggi. Denpasar: Pemda Tk. I Bali.

Utami, Desak Ketut Sri. 2010. Efektifitas Komunikasi Krama Banjar Adat Ceramcam Desa Pakraman Denpasar Timur. (Skripsi). Denpasar: IHDN Denpasar. 